\title{
Mineralogy of C-S-H belite hydrates incorporating Zn-Al-Ti layered double hydroxides
}

\author{
F. Amor ${ }^{1}$, A. Diouri ${ }^{1}$ and A. Boukhari ${ }^{1}$ \\ ${ }^{1}$ Laboratory of Applied Solid State Chemistry, Faculty of Sciences, Mohammed V University, Rabat, Morocco
}

\begin{abstract}
Recently, the belitic cements with low alite content were the subject of several research works which aimed to replace the Ordinary Portland Clinker (OPC) for ecological reasons (reduction of $\mathrm{CO}_{2}$ emissions), so to understand the reactivity of this cement, the hydration study of the $\mathrm{C}_{2} \mathrm{~S}$ "dicalcium silicate" phase is primordial research step. As well for a clean environment, the $\mathrm{TiO}_{2}$ photocatalyst has been extensively applied in the science of building materials because of its ability to degrade the cement surface pollutants. New photocatalyst based layered double hydroxides ( $\mathrm{LDH}$ ) associated with zinc, aluminium and $\mathrm{TiO}_{2}$ was introduced to increase the compatibility with mortars. The present work is subjected to investigate the effect of the layered double hydroxides on the hydration of $\mathrm{C}_{2} \mathrm{~S}$ in following the evolution of hydration by X-ray diffraction at 2, 7, 28 and 90 days and analyzing the calcium/silicon ratio of different formed hydrates.
\end{abstract}

\section{Introduction}

The ordinary Portland cement is a complex multiphase system, the hydration includes several simultaneous processes of dissolution/precipitation [1]. As soon as the cement is contacted with the gauging water, the silicate phases $\mathrm{C}_{3} \mathrm{~S}$ and $\mathrm{C}_{2} \mathrm{~S}$ react rapidly with $\mathrm{H}_{2} \mathrm{O}$ to form less soluble hydrates than these phases. Nevertheless, despite of the almost immediate forming of the first hydrates, the hydration may continue for many years to come [2]. When the cement is hydrated, the reactions during the gauging form the Calcium Silicate Hydrate C-S-H (notation in the cement industry $\mathrm{C}=\mathrm{CaO}$, $\mathrm{S}=\mathrm{SiO}_{2}$, and $\mathrm{H}=\mathrm{H}_{2} \mathrm{O}$ ) by releasing $\mathrm{Ca}^{2+}$ and $\mathrm{OH}^{-}$ions [3], these two species combine and form Portlandite. Dicalcium silicate $\mathrm{C}_{2} \mathrm{~S}$ gives the same products with low quantities and slow kinetics compared to $\mathrm{C}_{3} \mathrm{~S}$. In Portland cement the dicalcium silicate has three polymorphic forms $\alpha-\mathrm{C}_{2} \mathrm{~S}, \quad \beta-\mathrm{C}_{2} \mathrm{~S}$ and $\gamma-\mathrm{C}_{2} \mathrm{~S}$ (metastable) with a composition which varies between $20 \%$ and $25 \%$ in the clinker. The slower hydration of $\mathrm{C}_{2} \mathrm{~S}$, after 28 days, leads to improved long-term strength. Tests on alite and belite showed that long term strengths are comparable and that only the hydration kinetics is different [4].

$\mathrm{C}-\mathrm{S}-\mathrm{H}$ is the predominant phase resulting from the hydration of dry cement, it is directly responsible for the evolution of mechanical properties. In the literature, several studies show that the tobermorite-like structure is the closest to that of C-S-H [5]. There are three isomorphic structures of tobermorite which are distinguished by their basal space (distance between the two basic plans of two first lamellas neighbors): $9.3 \AA$, 11
$\AA[6,7]$ and $14 \AA$ [8]. According to the ratio of water/cement and $\mathrm{Ca} / \mathrm{Si}$, the $\mathrm{C}-\mathrm{S}-\mathrm{H}$ can adopt one of the isomorphous structures. Tobermorite is generally considered as a valid analogy for the C-S-H with low ratios $\mathrm{Ca} / \mathrm{Si}$, while jennite structure is used to describe the structure of C-S-H with high ratios $\mathrm{Ca} / \mathrm{Si}[9,10]$. Similarities between C-S-H and tobermorite were also deduced from atomic simulations [11], although this model is the subject of criticism [12]. The chemical composition and the unit cell of the clinotobermorite are closely linked to those of the tobermorite, it is very likely that the clinotobermorite is a stable polymorph at a lower temperature than the tobermorite [13]. Studies of the structure and the kinetic of C-S-H are essential so as to understand the process of the cement setting and the "sticking" mechanism at the microscopic level, their chemical composition is variable. In particular, the ratio $(\mathrm{Ca} / \mathrm{Si})$ of calcium-silicon structure is commonly assumed to vary from 0.6 to 2.3 , the highest ratio being found in the clean Portland cement, and the lowest in cements containing products such as fly ash or metakaolin $[14,15]$.

The layered double hydroxides LDH have spurred the interest many researchers, they are more likely useful as additions in cements. Cement based materials containing the nanoparticles have shown several benefits under distinct perspectives for sustainable construction practice, as well as, the kinetics of hydration acceleration [16]. Photocatalytic phenomena have become an attractive field of studies in the last decade because of its great potentials for the purification of the environment and the ability to break down aquatic and air pollutants $[17,18]$. 
Furthermore and as part of research on the reduction of pollutants in the atmosphere, the Portland cement is also studied for this aim by adding $\mathrm{TiO}_{2}$ which allows the degradation of air pollutants by photocatalysis. The photocatalytic principles are based on the free-radical reaction initiated by light onto a concrete surface. Its efficiency depends on the mobility of electron-hole pairs that determines the probability of electrons and holes to achieve contact with active sites on the photocatalyst surface [19]. The most commonly used photocatalyst is $\mathrm{TiO}_{2}$ due to its strong oxidizing power, its photo-stability and its non-toxicity. This oxide is already widely marketed for its properties and use in surface state [20, 21]. The titanium oxide properties can be improved when using double hydroxides lamellar based Zn-Al-Ti [22].

The introduction of the photocatalytic active inorganic-inorganic nanocomposites to the cement-based mortars improved overall mortar properties (microhardness and crystallinity) and showed that the synergetic effect between $\mathrm{TiO}_{2}$ as traditional photocatalytic and $\mathrm{Zn}$ Al-LDH contributes to the overall photocatalytic performances, improving also the compatibility of the photocatalytic active phase with the mortar matrix [23]. Zinc was selected as constituent LDH metal because of its photocatalytic and antimicrobial activity with the intention to possibly contribute to the overall activity of novel $\mathrm{Ti}-\mathrm{Zn}-\mathrm{Al}$ nanocomposite. $\mathrm{ZnO}$ is frequently looked as an alternative to $\mathrm{TiO}_{2}$, since it can absorb a larger energy fraction of the solar spectrum and more light quanta [24]. In our work, the LDH compounds after synthesis are added under a calcined form with a quantity of $\mathrm{ZnTiO}_{3}$, the compounds, thus introduced under a dried active form, are more likely to react to form again $\mathrm{LDH}$ structures that are themselves trapped in hydrates dicalcium silicate. Thermal treatment provides important physicochemical properties to LDH compounds [25]: a "memory effect" of the hydroxide lattice, which allows different anionic species to be incorporated into the LDH interlamellar space, a larger surface area, increasing adsorption of anions and elimination of the interlayer carbonate $\left(\mathrm{CO}_{3}{ }^{2-}\right)$, which strongly hinders anion exchange processes in LDHs [26, 27].

In this paper we seek to use LDH compounds and exploit their memory effect by heat treatment and addition to the $\mathrm{C}_{2} \mathrm{~S}$ phase to study the evolution of hydrates formed in these mixtures. The purpose is to make a mineralogical study of the hydrates of dicalcium silicate in the presence of varying amounts $(1 \%$ and 3 $\mathrm{wt} \%$ ) of layered double hydroxides $\mathrm{Zn}-\mathrm{Al}-\mathrm{Ti}$, monitoring of phases used is carried out by XRD after 2, 7, 28 and 90 days of hydration to compare the polymorphism of phase formation and determine the $\mathrm{Ca} / \mathrm{Si}$ in the formed phases.

\section{Materials and methods}

\subsection{Synthesis of $C_{2} S$}

The synthesis of the $\mathrm{C}_{2} \mathrm{~S}$ phase was performed by firing a silica source $\mathrm{SiO}_{2}$ finely ground with calcite $\left(\mathrm{CaCO}_{3}\right)$ and of $\left(\mathrm{NH}_{4}\right) \mathrm{H}_{2} \mathrm{PO}_{4}$ used as a dopant to stabilize the $\beta-\mathrm{C}_{2} \mathrm{~S}$ variety, the mixture is subjected to a heat treatment at different temperatures $500{ }^{\circ} \mathrm{C}, 800{ }^{\circ} \mathrm{C}$ and $1000{ }^{\circ} \mathrm{C}$ for 24,12 and $8 \mathrm{~h}$ respectively, followed by rapid air cooling. The heat treatments are interspersed by milling with the addition of ethanol whose role is to increase the reactivity of the products.

\subsection{Synthesis of $\mathrm{Zn}-\mathrm{Al}-\mathrm{Ti}$ Layered Double Hydroxides}

In a beaker an acid solution of $\mathrm{Zn}\left(\mathrm{NO}_{3}\right)_{2} 6 \mathrm{H}_{2} \mathrm{O}$, $\mathrm{Al}\left(\mathrm{NO}_{3}\right)_{3} 9 \mathrm{H}_{2} \mathrm{O}$ precursors and a basic solution of $\mathrm{Na}_{2} \mathrm{CO}_{3}$ and $\mathrm{NaOH}$ were simultaneously added $(4 \mathrm{~cm} 3 / \mathrm{min})$ so as to adjust a constant $\mathrm{pH}$ between 9 and 9.5 at a constant temperature of $45^{\circ} \mathrm{C}$ for 10 hours. A Zn-Al LDH white precipitate is formed after aging from $12 \mathrm{~h}$ at $100^{\circ} \mathrm{C}$ in a stove and calcined for 5 hours at $500{ }^{\circ} \mathrm{C}$. The wet impregnation of $\mathrm{TiO}_{2}$ on the $\mathrm{Zn}-\mathrm{Al}$ layered double hydroxide was used for the preparation of Zn-Al-Ti LDH. The wet impregnation process was carried out using $\mathrm{TiO}_{2}$ suspension diluted ( $3 \%$ by weight) in a base solution $0.67 \mathrm{M} \mathrm{Na}_{2} \mathrm{CO}_{3}$ and loaded on the calcined powder $\mathrm{Zn}-\mathrm{Al}$ $\mathrm{LDH}$. The excess water was removed in a stove at $100^{\circ} \mathrm{C}$. The impregnated sample is dried for a second time 12 hours at $100^{\circ} \mathrm{C}$ and calcined for 5 hours at $500{ }^{\circ} \mathrm{C}$ to finally obtain the powder $\mathrm{Zn}-\mathrm{Al}-\mathrm{Ti} \mathrm{LDH}$.

\subsection{Hydration of blended samples}

The resulting binders and the hydrated samples were analyzed by the X-ray diffraction performed by a Siemens D5000 diffractometer. This unit uses the mounting BRAGG-BRENTANO $(\theta / 2 \theta)$ and a radiation $\lambda_{\mathrm{K} \alpha} \mathrm{Cu}=1.5406 \AA$. The spectra $2 \theta$ interval is between 10 and $60^{\circ}$ (with a step of $0.04^{\circ}$ ).

Two samples are prepared from the synthesized $\mathrm{C}_{2} \mathrm{~S}$ phase and the addition of $1 \%$ and $3 \%$ by weight of $\mathrm{Zn}$ $\mathrm{Al}-\mathrm{Ti} \mathrm{LDH}$. The adopted nomenclature is given in table 1. The designation for example of sample C2S3LDH7d means that the addition of $3 \% \mathrm{LDH}$ is performed to $\mathrm{C}_{2} \mathrm{~S}$ and hydration of sample was followed for 7 days.

Table 1. Nomenclature of prepared samples

\begin{tabular}{ccc} 
Hydration time & $\begin{array}{c}\mathbf{C}_{2} \mathbf{S}+\mathbf{1 \%} \mathbf{Z n}-\mathbf{A l}-\mathbf{T i} \\
\mathbf{L D H}\end{array}$ & $\begin{array}{c}\mathbf{C}_{2} \mathbf{S}+\mathbf{3 \%} \mathbf{Z n}-\mathbf{A l}-\mathbf{T i} \\
\mathbf{L D H}\end{array}$ \\
\hline & & \\
2 days & C2S1LDH2d & C2S3LDH2d \\
7 days & C2S1LDH7d & C2S3LDH7d \\
28 days & C2S1LDH28d & C2S3LDH28d \\
90 days & C2S1LDH90d & C2S3LDH90d \\
& & \\
\hline
\end{tabular}

\section{Results and discussion}

\subsection{X-ray diffraction of the anhydrous samples}

The $\mathrm{C}_{2} \mathrm{~S}$ phase is synthesized by reacting of $\mathrm{CaCO}_{3}$ and $\mathrm{SiO}_{2}$ at $800^{\circ} \mathrm{C}$ and $1000^{\circ} \mathrm{C}$. The $\alpha-\mathrm{C}_{2} \mathrm{~S}$ form of 
orthorhombic variety with a large amount of $\mathrm{CaO}$ is manifested at $800^{\circ} \mathrm{C}$. At $1000^{\circ} \mathrm{C}$ the intensity of $\mathrm{CaO}$ peaks decreases with the appearance of a second form of $\mathrm{C}_{2} \mathrm{~S}\left(\beta-\mathrm{C}_{2} \mathrm{~S}\right)$ which has a monoclinic crystal system.

The X-ray diffractograms of the Zn-Al LDH and Zn-Al$\mathrm{Ti}$ LDH before and after calcinations are shown in Figures 1, 2, 3 and 4 .

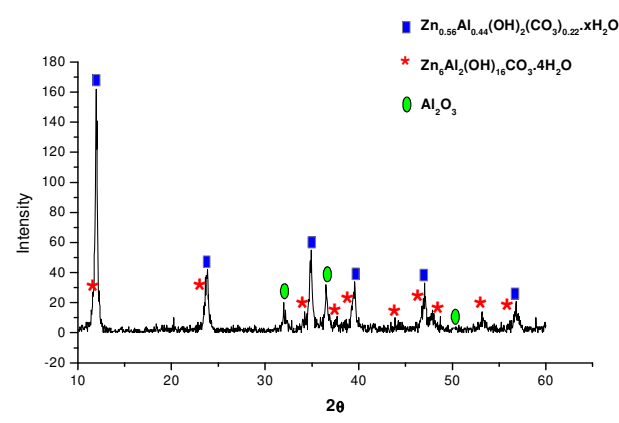

Fig. 1. XRD pattern of Zn-AL LDH phase before calcinations

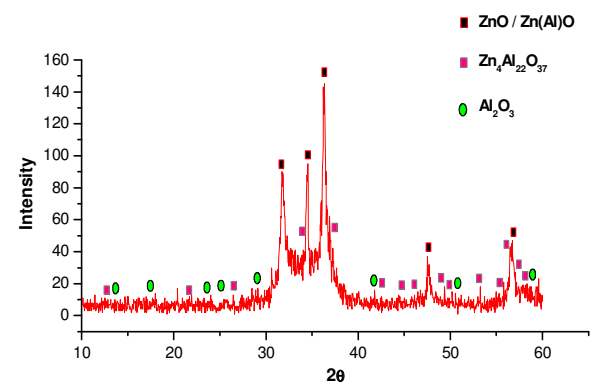

Fig. 2. XRD pattern of the $\mathrm{Zn}-\mathrm{Al} \mathrm{LDH}$ phase calcined at $500{ }^{\circ} \mathrm{C}$

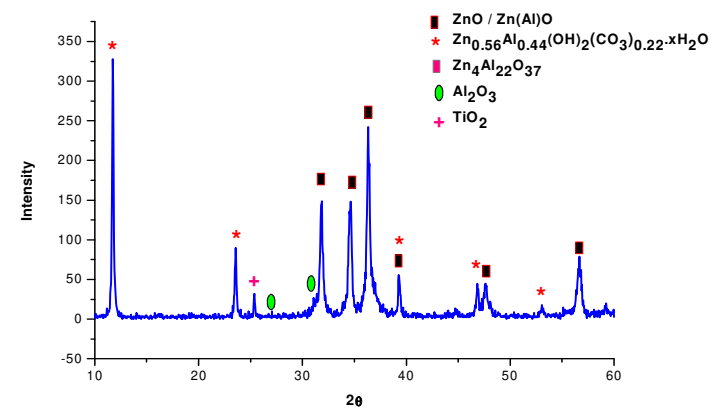

Fig. 3. XRD pattern of the Zn-Al-Ti LDH phase

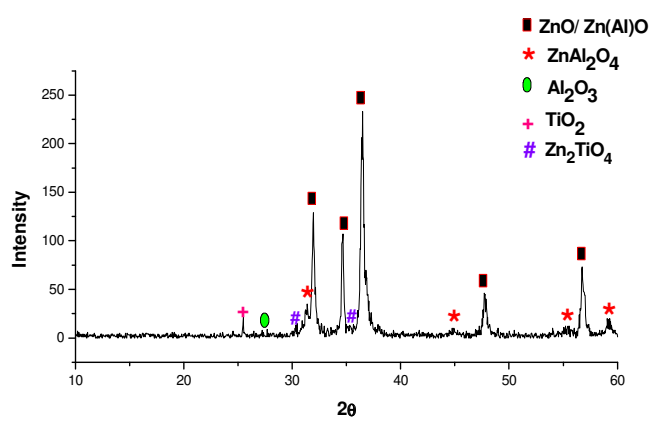

Fig. 4. XRD pattern of the $\mathrm{Zn}-\mathrm{Al}-\mathrm{Ti} \mathrm{LDH}$ phase calcined at $500^{\circ} \mathrm{C}$
The diffraction peaks demonstrates a LDH double layered hydroxides by forming two $\mathrm{LDH}$ phases: A stoichiometric phase $\mathrm{Zn}_{6} \mathrm{Al}_{2}(\mathrm{OH})_{16} \mathrm{CO}_{3} .4 \mathrm{H}_{2} \mathrm{O}$ and a nonstoichiometric phase $\mathrm{Zn}_{0.56} \mathrm{Al}_{0.44}(\mathrm{OH})_{2}\left(\mathrm{CO}_{3}\right)_{0.22} \cdot \mathrm{xH}_{2} \mathrm{O}$ was detected as the dominant phase. During the first calcination of $\mathrm{Zn}-\mathrm{Al} \mathrm{LDH}$ phase at $500^{\circ} \mathrm{C}$ we can note the disappearance of the diffraction peaks corresponding to $\mathrm{LDH}$, the structure is destroyed which resulted in the appearance of $\mathrm{ZnO}, \mathrm{Al}_{2} \mathrm{O}_{3}$ and $\mathrm{Zn}_{4} \mathrm{Al}_{22} \mathrm{O}_{37}$ and the disappearance of carbonates (figure 2). After impregnation of $\mathrm{TiO}_{2}$ onto $\mathrm{Zn}-\mathrm{Al} \mathrm{LDH}$ phase, $\mathrm{TiO}_{2}$ was not detected in diffractograms because of its low concentration. However the appearance of zinicite phase $\mathrm{ZnO}$ and aluminum oxide $\mathrm{Al}_{2} \mathrm{O}_{3}$ as well as $\mathrm{Zn}_{0.63} \mathrm{Al}_{0.37}(\mathrm{OH})_{2}\left(\mathrm{CO}_{3}\right)_{0.185} \times \mathrm{xH}_{2} \mathrm{O} \mathrm{LDH}$ phases were due to the hydration following the impregnation process (figure 3). After the second calcination the dominant phase detected is assigned to the mixed oxides of $\mathrm{ZnO}$ and $\mathrm{Al}_{2} \mathrm{O}_{3}$, since the origin of the $\mathrm{ZnO}$ phase is the $\mathrm{Zn}-\mathrm{Al}$ LDH $[28,29]$, we also noticed the disappearance of the LDH phase such as what occurred in the first calcination (Figure 2), which resulted in the formation of stable phases of $\mathrm{ZnO}, \mathrm{ZnAl}_{2} \mathrm{O}_{4}$ and $\mathrm{Zn}_{2} \mathrm{TiO}_{4}$. The reflections of the $\mathrm{TiO}_{2}$ anatase phase were detected, probably due to the titanium oxide that did not react with $\mathrm{ZnO}$ (Figure 4). These results are consistent with the work of Milica Hadnadjev-Kostic et al. [30].

The interest of the calcination of $\mathrm{Zn}_{6} \mathrm{Al}_{2}(\mathrm{OH})_{16} \mathrm{CO}_{3} .4 \mathrm{H}_{2} \mathrm{O}$ is to form $\mathrm{Zn}-\mathrm{Ti} \mathrm{LDH}$ by the reconstitution method, the formed $\mathrm{LDH}$ were calcinated at $500^{\circ} \mathrm{C}$ to remove nitrates and form the $\mathrm{ZnO}$ and $\mathrm{Zn}_{2} \mathrm{TiO}_{4}$ which is the essential final product for the photocatalytic activity [30]. The reconstruction of the LDH structure took place during the impregnation process under the effect of the mixed oxides of $\mathrm{ZnAl}$ who have the ability to re-establish the hydroxide lamellar structure when are exposed to water and anions [31], which will be used as an addition to the hydration of different samples of $\mathrm{C}_{2} \mathrm{~S}$.

\subsection{X-ray diffraction of hydrated samples}

Figure 5 shows the diffraction patterns of $\mathrm{C}_{2} \mathrm{~S}$ samples + $1 \%$ of $\mathrm{Zn}-\mathrm{Al}-\mathrm{Ti} \mathrm{LDH}$ hydrated for 2, 7, 28 and 90 days. Table 2 summarizes the semi-quantitative analysis of the formed hydrates and their $\mathrm{Ca} / \mathrm{Si}$ ratios as a function of time. The global $\mathrm{Ca} / \mathrm{Si}$ observed for total $\mathrm{C}-\mathrm{S}-\mathrm{H}$ phases is calculated as the sum of all proportions of each observed $\mathrm{C}-\mathrm{S}-\mathrm{H}$ phase multiplied by its own factor $\mathrm{Ca} / \mathrm{Si}$. 


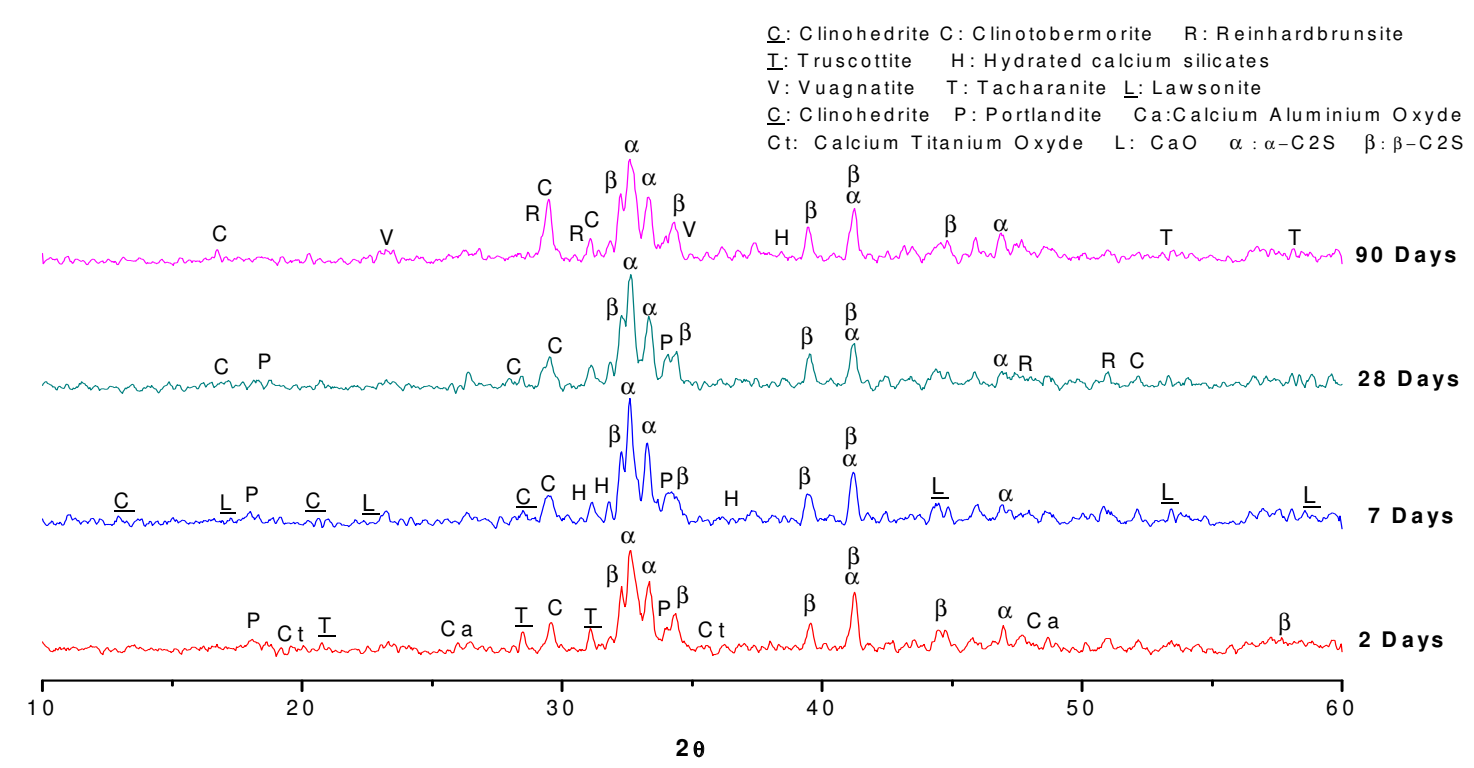

Fig. 5. XRD patterns of $\mathrm{C}_{2} \mathrm{~S}+1 \% \mathrm{Zn}$-Al-Ti LDH hydrated samples

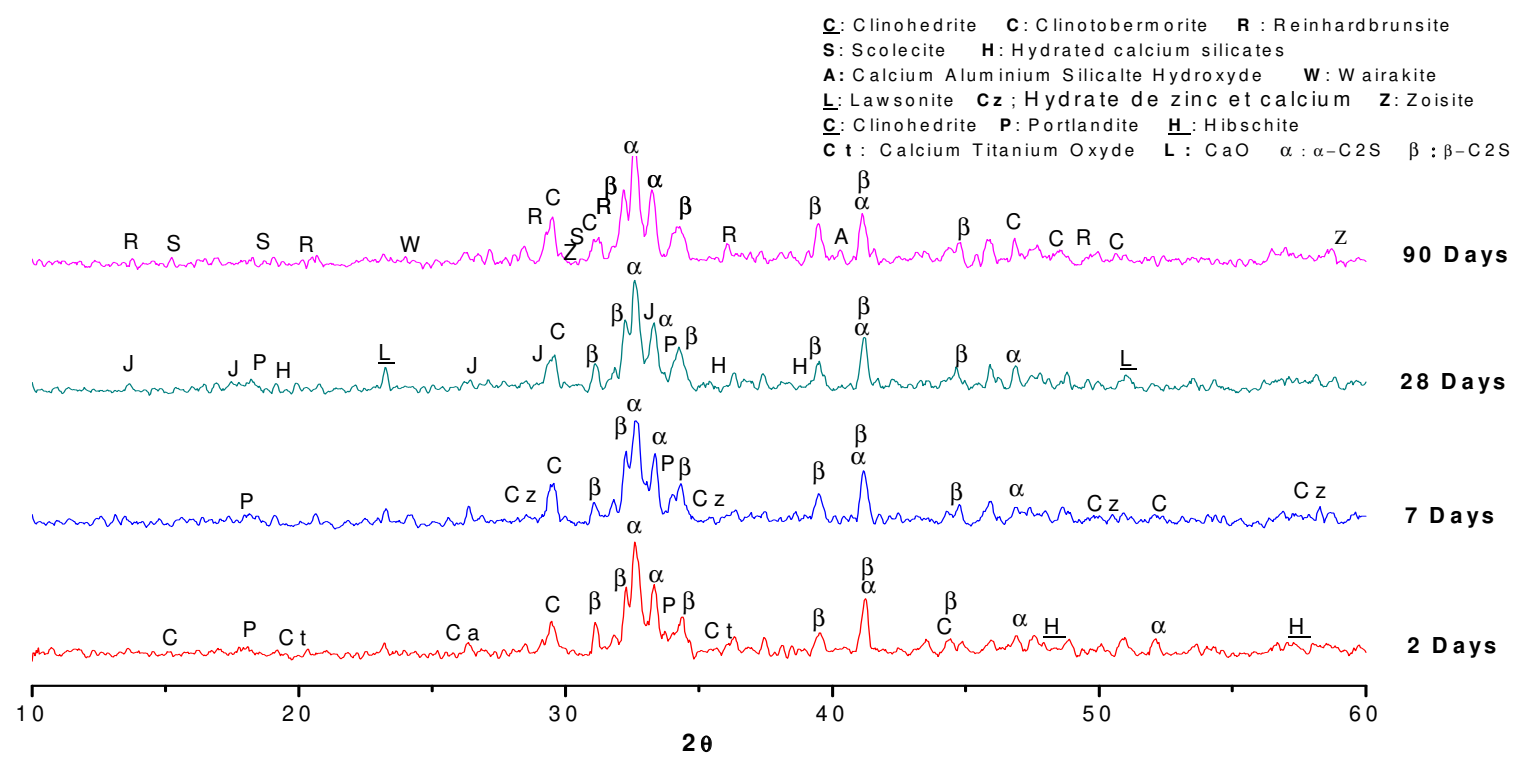

Fig. 6. XRD patterns of $\mathrm{C}_{2} \mathrm{~S}+3 \% \mathrm{Zn}-\mathrm{Al}-\mathrm{Ti} \mathrm{LDH}$ hydrated samples 
Table 2. Semi-quantitative analysis of hydrated samples with $1 \% \mathrm{Zn}-\mathrm{Al}-\mathrm{Ti} \mathrm{LDH}$

\begin{tabular}{|c|c|c|c|c|c|c|c|}
\hline & \multirow{2}{*}{ Phase nomenclature } & \multirow{2}{*}{ Formulas } & \multicolumn{4}{|c|}{ Percentages of hydrates } & \multirow{2}{*}{$\mathbf{C a} / \mathbf{S i}$} \\
\hline & & & 2 Days & 7 Days & 28 Days & 90 Days & \\
\hline \multirow{3}{*}{ 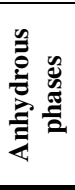 } & Dicalcique silicate & $\mathrm{Ca}_{2} \mathrm{SiO}_{4}$ & 41.27 & 34.59 & 23.62 & 20.13 & - \\
\hline & Calcium Titanium Oxyde & $\mathrm{Ca}_{4} \mathrm{Ti}_{3} \mathrm{O}_{10}$ & 1.03 & 1.17 & - & - & - \\
\hline & $\begin{array}{l}\text { Calcium Aluminium } \\
\text { Oxyde }\end{array}$ & $\mathrm{Ca}_{3} \mathrm{Al}_{2} \mathrm{O}_{6}$ & 6.05 & - & - & - & - \\
\hline \multirow{10}{*}{ 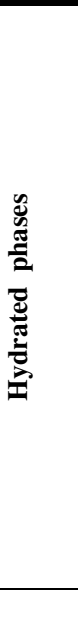 } & Portlandite & $\mathrm{Ca}(\mathrm{OH})_{2}$ & 8.80 & 9.24 & 13.22 & - & - \\
\hline & $\begin{array}{l}\text { Lawsonite } \\
\text { (C-S-H-Al) }\end{array}$ & $\mathrm{Ca}_{4} \mathrm{Al}_{8} \mathrm{Si}_{36} \mathrm{O}_{48} \cdot 16 \mathrm{H}_{2} \mathrm{O}$ & - & 13.73 & - & - & 0.11 \\
\hline & $\begin{array}{c}\text { Clinotobermorite } \\
(\mathrm{C}-\mathrm{S}-\mathrm{H})\end{array}$ & $\mathrm{Ca}_{5}\left(\mathrm{Si}_{6} \mathbf{O}_{17}\right)\left(\mathbf{H}_{2} \mathbf{O}\right)_{5}$ & 15.52 & 13.63 & 20.47 & 17.65 & 0.83 \\
\hline & $\begin{array}{c}\text { Truscottite } \\
\text { (C-S-H) }\end{array}$ & $\mathrm{Ca}_{14}\left(\mathrm{Si}_{24} \mathrm{O}_{58}\right)(\mathrm{OH})_{8}\left(\mathrm{H}_{2} \mathrm{O}\right)_{2}$ & 9.8 & - & - & - & 0.58 \\
\hline & $\begin{array}{l}\text { Clinohedrite } \\
(\mathrm{C}-\mathrm{S}-\mathrm{H}-\mathrm{Zn})\end{array}$ & $\mathrm{CaZn}\left(\mathrm{SiO}_{4}\right)\left(\mathrm{H}_{2} \mathrm{O}\right)$ & - & 12.22 & - & - & 1 \\
\hline & $\begin{array}{l}\text { Hydrate calcium silicates } \\
\text { (C-S-H) }\end{array}$ & $\mathrm{Ca}_{6} \mathrm{Si}_{3} \mathrm{O}_{12} \cdot \mathrm{H} 2 \mathrm{O}$ & - & 6.17 & - & 14.8 & 2 \\
\hline & $\begin{array}{c}\text { Reinhardbraunsite } \\
(\mathrm{C}-\mathrm{S}-\mathrm{H})\end{array}$ & $\mathrm{Ca}_{5}\left(\mathrm{SiO}_{4}\right)_{2}(\mathrm{OH})_{2}$ & - & - & 12.78 & 10.38 & 2.5 \\
\hline & $\begin{array}{l}\text { Tacharanite } \\
(\mathrm{C}-\mathrm{S}-\mathrm{H}-\mathrm{Al})\end{array}$ & $\mathrm{Ca}_{12} \mathrm{Al}_{2} \mathrm{Si}_{18} \mathrm{O}_{51} .18 \mathrm{H}_{2} \mathrm{O}$ & - & - & - & 6.7 & 0.67 \\
\hline & $\begin{array}{l}\text { Vuagnatite } \\
(\mathrm{C}-\mathrm{S}-\mathrm{H}-\mathrm{Al}) \\
\end{array}$ & $\mathrm{CaAlSiO}_{4}(\mathrm{OH})$ & - & - & - & 4.1 & 1 \\
\hline & \multicolumn{2}{|c|}{ Global $\mathrm{Ca} / \mathrm{Si}$ observed for total $\mathrm{CSH}$ phases } & 0.181 & 0.373 & 0.489 & 0.787 & \\
\hline
\end{tabular}

Table 3. Semi-quantitative analysis of hydrated samples with 3\% Zn-Al-Ti LDH

\begin{tabular}{|c|c|c|c|c|c|c|c|}
\hline & \multirow{2}{*}{ Phase nomenclature } & \multirow{2}{*}{ Formulas } & \multicolumn{4}{|c|}{ Percentages of hydrates } & \multirow{2}{*}{$\mathrm{Ca} / \mathrm{Si}$} \\
\hline & & & 2 Days & 7 Days & 28 Days & 90 Days & \\
\hline \multirow{3}{*}{ 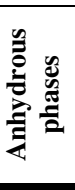 } & Silicate bicalcique & $\mathrm{Ca}_{2} \mathrm{SiO}_{4}$ & 47.32 & 40.80 & 38.74 & 29.84 & - \\
\hline & Calcium Titanium Oxyde & $\mathrm{Ca}_{4} \mathbf{T i}_{3} \mathbf{O}_{10}$ & 10.03 & - & - & - & - \\
\hline & $\begin{array}{l}\text { Calcium Zinc Titanium } \\
\text { Oxyde }\end{array}$ & $\mathrm{Ca}_{2} \mathrm{Zn}_{4} \mathrm{Ti}_{15} \mathrm{O}_{36}$ & 7.8 & - & - & - & - \\
\hline \multirow{14}{*}{ 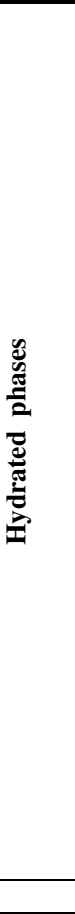 } & Portlandite & $\mathrm{Ca}(\mathrm{OH})_{2}$ & 8.019 & 10.4 & 11.06 & - & - \\
\hline & $\begin{array}{c}\text { Clinotobermorite } \\
\text { (C-S-H) }\end{array}$ & $\mathrm{Ca}_{5}\left(\mathrm{Si}_{6} \mathrm{O}_{17}\right)\left(\mathrm{H}_{2} \mathrm{O}\right)_{5}$ & 16.77 & 19.93 & 19.20 & 15.29 & 0.83 \\
\hline & $\begin{array}{c}\text { Hibschite } \\
(\mathrm{C}-\mathrm{S}-\mathrm{H}-\mathrm{Al})\end{array}$ & $\mathrm{Ca}_{3} \mathrm{Al}_{2}\left(\mathrm{SiO}_{4}\right)_{1.53}(\mathrm{OH})_{5.88}$ & 10.05 & - & - & - & 1.96 \\
\hline & $\begin{array}{l}\text { Silicates de calcium hydratés } \\
\text { (C-S-H) }\end{array}$ & $\mathrm{Ca}_{2} \mathrm{SiO}_{4} \cdot \mathrm{H}_{2} \mathrm{O}$ & - & 17.4 & - & - & 2 \\
\hline & $\begin{array}{c}\text { Hydrate de zinc et calcium } \\
(\mathrm{C}-\mathrm{S}-\mathrm{H}-\mathrm{Zn})\end{array}$ & $\mathrm{CaZn}_{2}(\mathrm{OH})_{6} \cdot 2 \mathrm{H}_{2} \mathrm{O}$ & - & 11.28 & - & - & - \\
\hline & $\begin{array}{c}\text { Lawsonite } \\
(\mathrm{C}-\mathrm{S}-\mathrm{H}-\mathrm{Al})\end{array}$ & $\mathrm{Ca}_{4} \mathrm{Al}_{8} \mathrm{Si}_{36} \mathrm{O}_{48 .} \cdot \mathbf{1 6 H}_{2} \mathrm{O}$ & - & - & 11.84 & - & 0.11 \\
\hline & $\begin{array}{l}\text { Jennite } \\
(\mathrm{CSH})\end{array}$ & $\mathrm{Ca}_{9} \mathrm{H}_{2} \mathrm{Si}_{6} \mathrm{O}_{18}(\mathrm{OH})_{8} \cdot 6 \mathrm{H}_{2} \mathrm{O}$ & & & 10.95 & - & 1.5 \\
\hline & $\begin{array}{l}\text { Hydrate calcium silicates } \\
\text { (C-S-H) }\end{array}$ & $\mathrm{Ca}_{6} \mathrm{Si}_{3} \mathrm{O}_{12 \cdot} \cdot \mathrm{H}_{2} \mathrm{O}$ & - & - & 8.32 & - & 2 \\
\hline & $\begin{array}{c}\text { Zoisite } \\
(\mathrm{C}-\mathrm{S}-\mathrm{H}-\mathrm{Al}) \\
\end{array}$ & $\mathrm{Ca}_{2} \mathrm{Al}_{3} \mathrm{Si}_{36} \mathrm{O}_{12}(\mathrm{OH})$ & - & - & - & 14.97 & 0.05 \\
\hline & $\begin{array}{c}\text { Wairakite } \\
(\mathrm{C}-\mathrm{S}-\mathrm{H}-\mathrm{Al})\end{array}$ & $\mathrm{CaAl}_{2} \mathrm{Si}_{4} \mathrm{O}_{12} .2 \mathrm{H}_{2} \mathrm{O}$ & - & - & - & 11.56 & 0.25 \\
\hline & $\begin{array}{l}\text { Reinhardbraunsite } \\
\text { (C-S-H) }\end{array}$ & $\mathrm{Ca}_{5}\left(\mathrm{SiO}_{4}\right)_{2}(\mathrm{OH})_{2}$ & - & - & - & 9.77 & 2.5 \\
\hline & $\begin{array}{c}\text { Scolecite } \\
(\mathrm{C}-\mathrm{S}-\mathrm{H}-\mathrm{Al})\end{array}$ & $\mathrm{CaAlSi}_{3} \mathrm{O}_{10} .3 \mathrm{H}_{2} \mathrm{O}$ & - & - & - & 9.50 & 0.33 \\
\hline & $\begin{array}{c}\text { Calcium Aluminium Silicalte } \\
\text { Hydroxyde } \\
\text { (C-S-H-Al) }\end{array}$ & $\mathrm{Ca}_{3} \mathrm{Al}_{2} \mathrm{SiO}_{4}(\mathrm{OH})_{8}$ & - & - & - & 9.04 & 3 \\
\hline & \multicolumn{2}{|c|}{ Global Ca/Si observed for total CSH phases } & 0.336 & 0.513 & 0.622 & 1.103 & \\
\hline
\end{tabular}


Analysis of results shows that the main products of hydration of the $\mathrm{C}_{2} \mathrm{~S}$ phase $+1 \% \mathrm{Zn}$-Al-Ti LDH are $\alpha$ $\mathrm{C}_{2} \mathrm{~S}$ and $\beta-\mathrm{C}_{2} \mathrm{~S}$ phases, Portlandite and hydrated calcium silicates. We notice that the $\mathrm{C}-\mathrm{S}-\mathrm{H}$ phases are present in forms of different solid solutions including different proportions of $\mathrm{Al}$ and $\mathrm{Zn}$. On the 2nd day of hydration, we have a small amount of $\mathrm{C}-\mathrm{S}-\mathrm{H}$ phases whose presence is of formulas $\mathrm{Ca}_{5}\left(\mathrm{Si}_{6} \mathrm{O}_{17}\right)\left(\mathrm{H}_{2} \mathrm{O}\right)_{5}$ et $\mathrm{Ca}_{14}\left(\mathrm{Si}_{24} \mathrm{O}_{58}\right)(\mathrm{OH})_{8}\left(\mathrm{H}_{2} \mathrm{O}\right)_{2}$. On the 7 th day of hydration, there is the appearance of other hydrates of formulas $\mathrm{Ca}_{6} \mathrm{Si}_{3} \mathrm{O}_{12} \cdot \mathrm{H}_{2} \mathrm{O}$ and $\mathrm{CaZn}\left(\mathrm{SiO}_{4}\right)\left(\mathrm{H}_{2} \mathrm{O}\right)$ with decreasing percentage of Clinotobermorite, while the content of Portlandite continues to increase. After 28 days of hydration, we observe fluctuations in the amounts of this phase accompanied by appearance of other compounds such us hydrates incorporating the LDHs. These last phases have been identified in the forms of $\mathrm{CaZn}\left(\mathrm{SiO}_{4}\right)\left(\mathrm{H}_{2} \mathrm{O}\right)$ and $\mathrm{Ca}_{4} \mathrm{Al}_{8} \mathrm{Si}_{36} \mathrm{O}_{48} \cdot 16 \mathrm{H}_{2} \mathrm{O}$. We observe also the formation of the $\mathrm{Ca}_{5}\left(\mathrm{SiO}_{4}\right)_{2}(\mathrm{OH})_{2}$ phase with a percentage of $12.78 \%$ with a slight decrease of $\mathrm{C}_{2} \mathrm{~S}$ phase and the total consumption of the Portlandite $\mathrm{Ca}(\mathrm{OH})_{2}$, these results are consistent with the work of $\mathrm{H}$. ElDidamony et al. [32]. The hydrated phases formed at a young age, before 7 days, are essentially constituted by cristalline phases with low ratio $\mathrm{Ca} / \mathrm{Si}$ less than 1 while in the medium term, 28 to 90 days, the identified phases become morerich in calcium and the $\mathrm{Ca} / \mathrm{Si}$ ratio increases and may exceed 2 . The hydration of $\mathrm{C}_{2} \mathrm{~S}$ shows the presence of crystallized $\mathrm{C}-\mathrm{S}-\mathrm{H}$ compounds with percentages that increase and become more abundant in the 90th day, this is explained by the known character of this phase whose hydration is slow and participates in the creation of long-term resistances [2].

Figure 6 shows the diffraction patterns of $\mathrm{C}_{2} \mathrm{~S}$ samples + $3 \%$ of $\mathrm{Zn}$-Al-Ti LDH hydrated for 2, 7, 28 and 90 days. Table 3 summarizes the semi-quantitative analysis of the formed hydrates and their $\mathrm{Ca} / \mathrm{Si}$ ratios as a function of time. The observations for the sample with $3 \% \mathrm{Zn}-\mathrm{Al}-\mathrm{Ti}$ LDH addition are similar to those attributed to the sample with $1 \%$ of the added. From the spectra of Figure 6 and table 3 we can see the formation of the clinotobermorite $\mathrm{Ca}_{5}\left(\mathrm{Si}_{6} \mathrm{O}_{17}\right)\left(\mathrm{H}_{2} \mathrm{O}\right)_{5} \quad \mathrm{C}-\mathrm{S}-\mathrm{H}$ type and Portlandite $\mathrm{Ca}(\mathrm{OH})_{2}$ which are the main hydration products calcium silicates. Depending on the hydration time, the content of the clinotobermorite is variable and accompanied by the formation of jennite $\mathrm{Ca}_{9} \mathrm{H}_{2} \mathrm{Si}_{6} \mathrm{O}_{18}(\mathrm{OH})_{8} \cdot 6 \mathrm{H}_{2} \mathrm{O}(\mathrm{C}-\mathrm{S}-\mathrm{H})$. The $\mathrm{Zn}-\mathrm{Ti}-\mathrm{Al} \mathrm{LDH}$ phases also interacted in this hydration by hydrate formation where $\mathrm{Zn}$ and $\mathrm{Al}$ are incorporated, these hydrates appear since the second day of hydration, they have formulas of $\mathrm{CaZn}_{2}(\mathrm{OH})_{6} \cdot 2 \mathrm{H}_{2} \mathrm{O}$ and $\mathrm{Ca}_{4} \mathrm{Al}_{8} \mathrm{Si}_{36} \mathrm{O}_{48} \cdot 16 \mathrm{H}_{2} \mathrm{O}$.

From the tables 2 and 3 we plot versus time the $\mathrm{Ca} / \mathrm{Si}$ ratios of different hydrates formed (Figure 7), which clearly shows that in dependence of time the global $\mathrm{Ca} / \mathrm{Si}$ ratio increases with time hydration, and that the $\mathrm{Ca} / \mathrm{Si}$ ratios with the addition of $1 \%$ of $\mathrm{Zn}-\mathrm{Al}-\mathrm{Ti} \mathrm{LDH}$ are lower than those with $3 \%$ of addition. These results agree well with several studies showing that the variation of the stoichiometry of $\mathrm{C}-\mathrm{S}-\mathrm{H}$ in terms of the ratio $\mathrm{Ca} / \mathrm{Si}$ varies with the concentration of lime in the solution in which it is in equilibrium, so the higher lime concentration, the ratio $\mathrm{Ca} / \mathrm{Si}$ of $\mathrm{C}-\mathrm{S}-\mathrm{H}$ is higher $[33,34]$.

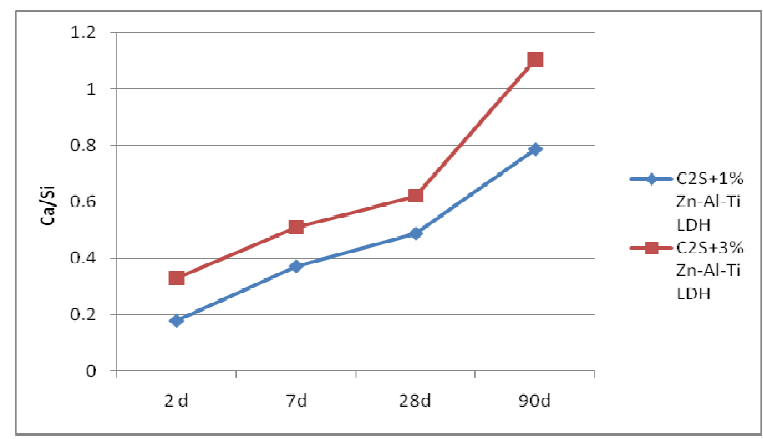

Fig. 7. Evolution of the global $\mathrm{Ca} / \mathrm{Si}$ ratio of hydrated samples as a function of time

\section{Conclusion}

This study examines the mineralogical aspects of hydration of belite phase incorporating Zn-Al-Ti layered double hydroxides in time when the proportions of $\mathrm{Zn}$ Al-Ti LDH varied of $1 \%$ and $3 \%$. The results can be summarized as follows:

- As a function of the hydration time we observe a slow increasing of the formed $\mathrm{C}-\mathrm{S}-\mathrm{H}$ and a decrease in the Portlandite phase $\mathrm{Ca}(\mathrm{OH})_{2}$, this may contribute to the increase of the mechanical resistances of the $\mathrm{C}_{2} \mathrm{~S}$ phase known having a slow hydration character and which participates essentially in the creation of long-term resistance.

- The basic elements of Zn-Ti-Al LDH interacted in the $\mathrm{C}-\mathrm{S}-\mathrm{H}$ phases that are presented in forms of different solid solutions including different proportions of $\mathrm{Al}$ and $\mathrm{Zn}$.

- The hydrated phases formed (before 7 days), are essentially constituted by crystalline phases with low ratio $\mathrm{Ca} / \mathrm{Si}$ less than 1 while in the medium term, 28 to 90 days, the identified phases become more rich in calcium and the $\mathrm{Ca} / \mathrm{Si}$ ratio increases and may exceed 2 such as in the formation of Reinhardbraunsite $\mathrm{Ca}_{5}\left(\mathrm{SiO}_{4}\right)_{2}(\mathrm{OH})_{2}$.

\section{References}

1. H. F. W. Taylor, Cement Chemistry, 2 ème edition, Edition Thomas Telford. Londres (1997)

2. N.B. Singh, Hydrothermal Synthesis of $\beta$-Dicalcium Silicate $\left(\beta-\mathrm{Ca}_{2} \mathrm{SiO}_{4}\right)$. Prog. Cryst. Growth. Ch. 52, 77-83 (2006)

3. S. Goñi, F. Puertas, M. S. Hernández. Quantitative study of hydration of $\mathrm{C}_{3} \mathrm{~S}$ and $\mathrm{C}_{2} \mathrm{~S}$ by thermal analysis. Evolution and composition of $\mathrm{C}-\mathrm{S}-\mathrm{H}$ gels formed. J. Therm. Anal. Calorim. 102 965-973 (2010)

4. H.F.W. Taylor, Proposed structure for calcium silicate hydrate gel. J. Am. Ceram. Soc. 69(6) 464467 (1986) 
5. M. Medala. Etude des interactions entre les phases minérales constituants le ciment portland et des solutions salines concentrées. PhD thesis, Université de Bourgogne, UFR des Sciences et Techniques, (2005)

6. S. A. Hamid, The crystal-structure of the $11 \AA$ naturel tobermorite $\mathrm{CA}_{2.25}\left[\mathrm{Si}_{3} \mathrm{O}_{7.55}(\mathrm{OH})_{1.5}\right] .1 \mathrm{H}_{2} \mathrm{O}$. Zeitchrift fur kristallographie, 154 (3-4) 189-198 (1981)

7. S. Merlino, E. Bonaccorsi and Armbruster. The real structure of tobermorite $11 \AA$ : normal and anormalous forms. Eur J Mineral. 13 577-590 (2001)

8. E. Bonaccorsi, S. Merlino and A. R. Kumpf. The crystal structure of tobermorite $14 \AA$ (plombierite), a C-S-H phase. J. Am. Ceram. Soc. 88 505-512 (2005)

9. I.G. Richardson, The calcium silicate hydrates. Cem. Concr. Res. 38 137-158 (2008)

10. Taylor, H. F., Proposed structure for calcium silicate hydrate gel J. Am. Ceram. Soc. 69 464-467 (1986)

11. R. J. Pellenq, A. Kushima, R. Shahsavari, K. J. Van Vliet, M. J. Buehler, S. Yip, F. J. Ulm, Proc. Natl Acad. Sci. USA, 106 16102-16107 (2009)

12. I. G. Richardson, The importance of proper crystalchemical and geometrical reasoning demonstrated using layered single and double hydroxides. Acta Cryst. B 69 150-162 (2013)

13. C. HENMI, I. KUSACHI, Clinotobermorite, $\mathrm{Ca}_{5} \mathrm{Si}_{6}(\mathrm{O}, \mathrm{OH})_{18} .5 \mathrm{H}_{2} \mathrm{O}$, a new mineral from Fuka, Okayama Prefecture, Japan. Mineralogical magazine 353-358 (1992)

14. A. Girao, I. Richardson, R. Taylor \& R.M.D. Brydson, Composition, morphology and nanostructure of $\mathrm{C}-\mathrm{S}-\mathrm{H}$ in $70 \%$ white Portland cement-30\% fly ash blends hydrated at $55{ }^{\circ} \mathrm{C}$. Cem. Concr. Res. 40 1350-1359 (2010)

15. I. Richardson, The nature of $\mathrm{C}-\mathrm{S}-\mathrm{H}$ in hardened cements Cem. Concr. Res. 29 1131-1147 (1999)

16. L. Senff, JA. Labrincha, VF. Ferreira, D. Hotza , WL. Repette, Effect of nano-silica on rheology and fresh properties of cement pastes and mortars. Constr Build Mater. 235 2487-91 (2009)

17. G. Sivalingham, K. Nagaveni, M.S. Hegde, G. Madras, Photocatalytic degradation of various dyes by combustion synthesized nanoanatase $\mathrm{TiO}_{2}$, Appl. Catal. B 45 23-38 (2003)

18. M. Hadnadjev, J. Ranogajec, S. Petrovic, S. Markov, V. Ducman, R. Marinkovic- Neducin, Design of selfcleaning $\mathrm{TiO}_{2}$ coating on clay roofing tiles, Phil. Mag. 90 (22) 2989-3002 (2010)

19. G. Flores, J. Carrillo, J.A. Luna, R. Martínez, A. Sierra-Fernandez, O. Milosevic, M.E. Rabanal, Synthesis,characterization and photocatalytic properties 5 of nanostructured $\mathrm{ZnO}$ particles obtained by low temperature 6 air-assisted-USP, Adv. Powder Technol. 25 1435-1441 (2014)

20. K.-J. Hwang, J.-W. Lee, W.-G. Shim, H.D. Jang, S.I. Lee, S.-J. Yoo, Adsorption and photocatalysis of nanocrystalline $\mathrm{TiO} 2$ particles prepared by sol-gel method for methylene blue degradation, Adv. Powder Technol. 23 414-418 (2012)
21. A. Fujishima, X. Zhang, D.A. Tryk, $\mathrm{TiO}_{2}$ photocatalysis and related surface phenomena, Surf. Sci. Rep. 63 515-582 (2008)

22. O. Rudic, D. Rajnovic, D. Cjepa, S. Vucetic, J. Ranogajec, Investigation of the durability of porous mineral substrates with newly designed $\mathrm{TiO}_{2}-\mathrm{LDH}$ coating. Ceram. Int. 41 9779-9792 (2015)

23. T. Vulic, M. Hadnadjev-Kostic, O. Rudic, M. Radeka, R. Marinkovic-Neducin, J. Ranogajec, Improvement of cement-based mortars by application of photocatalytic active $\mathrm{Ti}-\mathrm{Zn}-\mathrm{Al}$ nanocomposites. Cement\&Concrete Composites. 36 121-127 (2013)

24. S. Sakthivel, B. Neppolian, MV. Shankar, B. Arabindoo, M. Palanichamy, V. Murugesan, Solar photocatalytic degradation of azo dye: comparison of photocatalytic efficiency of $\mathrm{ZnO}$ and $\mathrm{TiO}_{2}$. Solar Energy Mater Sol Cells. 77 65-82 (2003)

25. H. Pfeiffer, E. Lima, V. Lara, J.S Valente, Thermokinetic Study of the Rehydration Process of a Calcined MgAl-Layered Double Hydroxide. Langmuir. 26(6) 4074-4079 (2010)

26. S.B Ghorbel, F. Medina, A. Ghorbel, A.M Segarra, Phosphoric acid intercalated $\mathrm{Mg}-\mathrm{Al}$ hydrotalcite-like compounds forcatalytic carboxylation reaction of methanol in a continuous system. Appl Catal., A. 493 142-148 (2015)

27. X. Cheng, X. Huang, X. Wang, B. Zhao, A. Chen, D. Sun, Phosphate adsorption from sewage sludge filtrate using zinc-aluminum layered double hydroxides. J. Hazard. Mater. 169 958-964 (2009)

28. M. Hadnadjev-Kostic, T. Vulic, D. B. Zoric, R. P. Marinkovic-Neducin, The influence of the UV irradiation intensity on photocatalytic activity of $\mathrm{ZnAl}$ - layered double hydroxides and derived mixed oxides, Chem. Ind. Chem. Eng. Quarter. 18 (2) 295303 (2012)

29. D. Carriazo, M. del Arco, E. Garcia-Lopez, G. Marci, C. Martin, L. Palmisano, V. Rives, Zn, Al hydrotalcites calcined at different temperatures: Preparation, characterization and photocatalytic activity in gas-solid regime, J. Mol. Catal. A: Chem. 342-343 83-90 (2011)

30. M. Hadnadjev-Kostic , T. Vulic, R. MarinkovicNeducin. Solar light induced rhodamine B degradation assisted by $\mathrm{TiO}_{2}-\mathrm{Zn}-\mathrm{Al} \mathrm{LDH}$ based photocatalysts. Adv. Powder Technol. 25 1624-1633 (2014)

31. J. Liua, G. Zhang, Recent advances in synthesis and applications of clay-based photocatalysts: a review, Phys. Chem. Chem. Phys. 16 8178-8192 (2014)

32. H. El-Didamony, A.M. Shararab, I.M. Helmy and S. Abd El-Aleem, Hydration characteristics of $\beta-C 2 S$ in the presence of some accelerators. Cem. Concr. Res. 26 1179-1 187 (1996)

33. M. W. Grutzek, A. Benesi, and B. Fanning, 29Si magic angle spinning nuclear magnetic resonancestudy of tricalcium silicate hydrate. J. Am. Ceram. Soc. 72 665-668 (1989)

34. H.F.W. Taylor, Hydrated calcium silicates. Part 1. Compound formation at ordinary temperatures .J. Chem. Soc 3682-3690 (1950) 